\title{
Occurrence and phylogenetic analysis of allexiviruses identified on garlic from China, Spain and Poland commercially available on the polish retail market
}

\author{
Maria Bereda • Elżbieta Paduch-Cichal • \\ Elżbieta Dąbrowska
}

Accepted: 24 January 2017 / Published online: 25 February 2017

(C) The Author(s) 2017. This article is published with open access at Springerlink.com

\begin{abstract}
Garlic plants can be infected by different viruses including eight which belong to the genus Allexivirus, family Alphaflexiviridae. The aim of the research conducted was to detect and identify the allexiviruses GarV-A, GarV-B, GarV-C, GarV-D, GarV-X, GarMbFV and ShVX in garlic (Allium sativum L.) bulbs imported into Poland from China and Spain, and those growing in Poland by ELISA (enzyme-linked immunosorbent assay) as well as reverse transcription polymerase chain reaction (RT-PCR). Bulbs tested were infected with one or more viruses, including species not previously recorded in Poland. Present in various combinations from 146 garlic bulbs were 83 virus isolates representing Garlic virus A, B, D, X and GarMbFV. The most genetically distinct population comprises isolates of GarV-X, while isolates of GarV-B and GarV-D seem to be genetically more uniform. GarMbFV isolates are also genetically uniform, except for isolates from South Korea and Argentina. The high sequence identity of isolates from China, Spain and Poland, detected in this study, probably results from the transmission of the viruses via a vector.
\end{abstract}

Keywords Allexiviruses · Imported garlic $\cdot$ Virus vector $\cdot$ Phylogenetic analysis

\footnotetext{
M. Bereda $(\square) \cdot$ E. Paduch-Cichal $\cdot$ E. Dąbrowska Department of Plant Pathology, Warsaw University of Life Sciences-SGGW, Nowoursynowska 159, 02-776 Warsaw, Poland e-mail: maria_bereda@sggw.pl
}

Allium sativum L. belongs to the family Liliaceae. It is one of the oldest crop plants and it is not only a valued spice plant, but also a major pharmaceutical raw material due to its health properties (Marjanowski 1988). The conditions in Poland are beneficial for the cultivation of garlic, which results in an increased area of garlic crops for direct consumption and the processing industry. The domestic production of garlic is about $15-20,000$ tons and is conducted on an area of around 3000 ha. Apart from domestic garlic crops, material from different parts of the world is also available on the Polish retail market. In recent years garlic has been imported mainly from China and Spain.

Because garlic bulbs do not produce viable seed, they are propagated vegetatively. Therefore garlic is susceptible to the accumulation of a range of viruses, including members of the genera Potyvirus, Carlavirus and Allexivirus. Elimination of these pathogens is problematic, because it involves the production of virus-free plants by meristem-tip culture (Conci et al. 2010).

Allexiviruses formed the most sizable group of garlic viruses. The serious damage of viruses from the genus Allexivirus in garlic cultivations is mainly due to a significant decrease of crop quality (Cafrune et al. 2006; Perotto et al. 2010).

The Allexivirus genus comprises: Garlic mite-borne filamentous virus (GarMbFV), Garlic virus A (GarV-A), Garlic virus B (GarV-B), Garlic virus $C$ (GarV-C), Garlic virus D (GarV-D), Garlic virus E (GarV-E), Garlic virus $X$ (GarV-X) and Shallot virus $X$ (ShVX) (King et al. 2012). Allexiviruses were first detected in shallot in Russia (Vishnichenko et al. 1993). They are 
now known to occur in various parts of the world. The allexiviruses have been recorded in garlic (Allium sativum L.) plants in Argentina (Conci et al. 1992), Japan (Sumi et al. 1993), Russia (Vishnichenko et al. 1993), Korea (Song et al. 1997), Greece (Dovas et al. 2001), Italy (Dovas and Vovlas 2003), Brazil (MeloFilho et al. 2004), China (Chen et al. 2004), Spain (Tabanelli et al. 2004), the Czech Republic (Klukáčková et al. 2007), Iran (Shahraeen et al. 2008), New Zealand (Ward et al. 2009), the USA (Gieck et al. 2009), Australia (Wylie et al. 2012), Poland (Chodorska et al. 2012, 2013), Sudan (Mohammed et al. 2013), India (Singh et al. 2014) and Ethiopia (Jemal et al. 2015).

Research on allexiviruses in Poland has been conducted since 2010. Chodorska et al. (2012, 2013) detected GarV-A, GarV-B, GarV-C, GarV-D, GarV-E and GarV-X in garlic bulbs collected from production fields located in five geographical districts of Poland: northern (Pomerania province), east-central (Mazovia and Łódź provinces), west-central (Wielkopolska province), southern (Małopolska and Silesia provinces) and south-western (Lower Silesia and Opole provinces). In a recent study ShVX was detected in A. caeruleum in Poland (Bereda and Paduch-Cichal 2016). To-date, only GarMbFV has not been detected in Poland.

Plant pathogens are difficult to control because their populations are variable in time, space, and genotype. In order to combat the losses they cause, it is necessary to define the problem and seek remedies. The tasks of the State Plant Health and Seed Inspection Service in Poland related to phytosanitary supervision include control and prevention of spread of harmful organisms, support for agricultural producers with the control of hostile organisms and the assurance of the appropriate health standards of plant material marketed in Poland and moved to other Member States of the European Union (EU) or exported outside the EU. However, control of garlic crops is difficult due to the possibility of the use of imported garlic bulbs as propagating material without the rules of phytosanitary control being followed.

Therefore, the first stage of our research involved checking for the occurrence of GarV-A, GarV-B, GarV-C, GarV-D, GarV-X, GarMbFV and ShVX in garlic plants from Chinese, Spanish and Polish crops commercially available in Poland using ELISA tests (enzyme-linked immunosorbent assay) as well as the RT-PCR technique (reverse transcription polymerase chain reaction). Isolates selected from positive samples were sequenced and used for further analysis.
From 2015 to 2016 garlic bulbs imported from China and Spain were collected from retail stores in Warsaw, Central Poland. Also garlic bulbs originating from Poland available in retail fruit and vegetable stores were collected. A total of 146 bulb samples were tested. Virus detection was first performed by DAS-ELISA with specific antibodies against GarV-A, GarV-B, GarV-C and ShVX obtained from Leibniz Institut DSMZ-German Collection of Microorganisms and Cell Cultures (Braunschweig, Germany). Samples were prepared by grinding $0.5 \mathrm{~g}$ of fresh leaves or bulbs in phosphate buffer saline supplemented with $2 \%$ polyvinylpyrrolidone and $0.2 \%$ egg albumin in the ratio of 1:10 (w:v) and tested according to the manufacturer's protocol. After $1 \mathrm{~h}$ of incubation at room temperature, substrate hydrolysis was measured as the change in absorbance at OD $405 \mathrm{~nm}$ using an Infinite 200Pro microplate reader (Tecan, Austria GmbH). Samples were considered positive if their optical density (OD $405 \mathrm{~nm}$ ) readings were at least twice those of healthy controls.

Total RNA was extracted from the positive samples using the silica capture (SC) method described originally by Boom et al. (1990) and adapted to the diagnosis of plant viruses by Malinowski (1997) and quantified by spectrophotometric measurement. RNA extracts were subjected to translation and amplification by reverse transcription-polymerase chain reaction (RT-PCR) using the Transcriptor One-Step RT-PCR Kit (Roche Applied Science, Germany). RT-PCR with total RNA and appropriate primers (Table 1) was used to confirm DAS-ELISA results and to detect and identify isolates of GarV-D, GarV-X and GarMbFV in garlic plants. A specific primer pair was designed by the authors from consensus sequences available in GenBank sequence database and synthesized for amplifying the region including complete capsid protein (CP) and nucleic acid binding protein (NABP) genes of GarV-A, GarV-B, GarV-C, GarV-D and GarV-X. The primer pair for detection of ShVX was designed in the open reading frame I (ORFI, replicase), and the primer pair for GarMbFV detection was designed in the part of the coat protein gene. The positive and negative controls in ELISA test and RT-PCR were from the commercial ELISA kit (DSMZ, Braunschweig, Germany). After RT-PCR, amplicons of the expected size were ligated to the pCRTM4-TOPO vector in accordance with the manufacturer's instructions (Invitrogen, Carlsbad, CA, USA). Two clones of each isolate were sequenced in both directions with universal T3 and T7 primers. The 


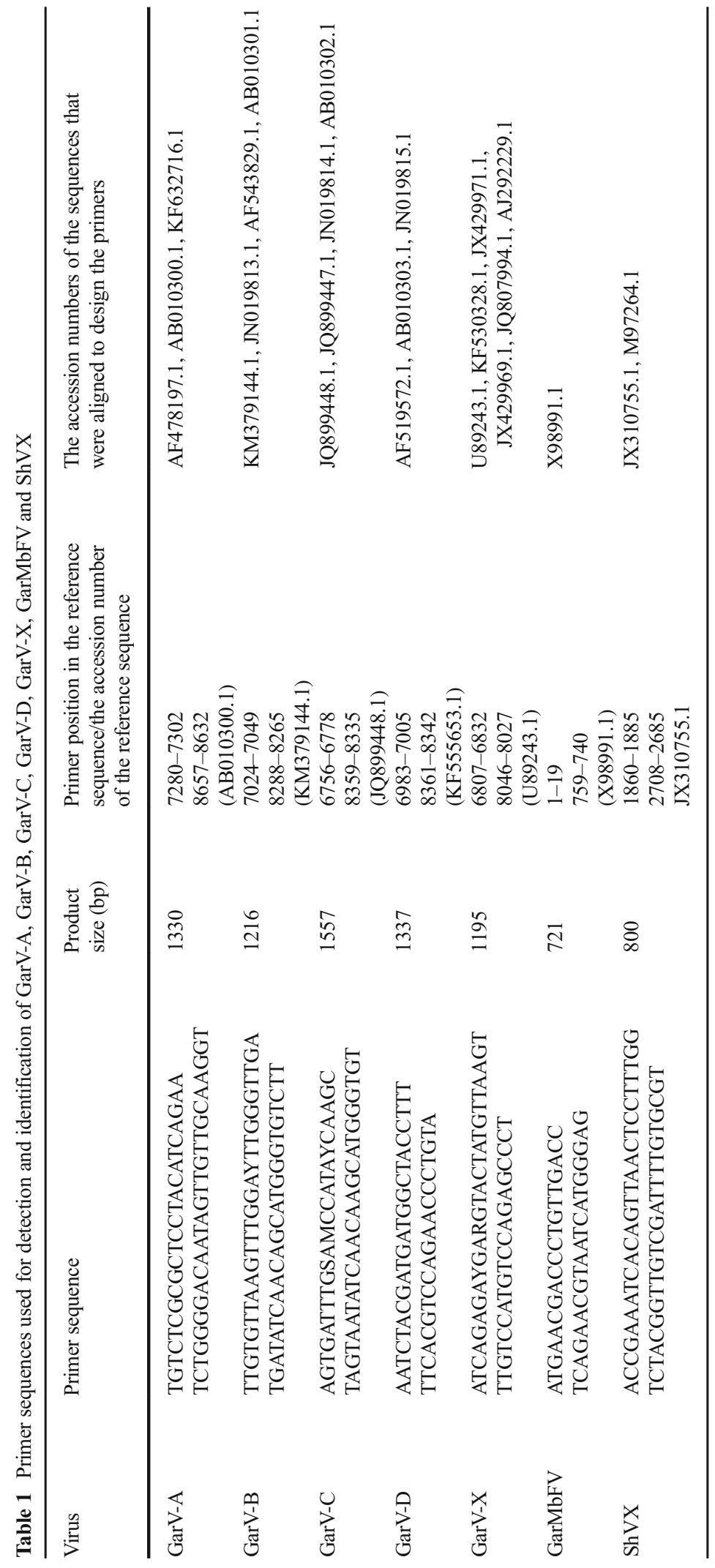


nucleotide sequences were determined using an ABI 3730 Genetic Analyzer (Applied Biosystems, Foster City, CA). Sequence data were assembled using DNA Baser Sequence Assembler ver. 4 (Heracle BioSoft, Romania). Sequence alignments were constructed in MEGA ver. 5 (Tamura et al. 2011). Sequences of other isolates used in this study, originating from different parts of the world, were retrieved from GenBank. Sequence similarity and identity analysis was performed in BioEdit (Hall 1999). Phylogenetic trees were constructed with MEGA5 using the maximumlikelihood (ML) and neighbor joining (NJ) methods with 1000 bootstrap replications. Shallot virus $X$ was used as outgroup.

All tested plants were infected with at least two allexiviruses (Table 2). The presence of GarV-A, GarV-B and GarV-C was detected by DAS-ELISA and confirmed by RT-PCR. Products of the expected size were amplified only from the DAS-ELISA-positive samples. RT-PCR with the appropriate primers also revealed the presence of GarV-D, GarV-X and GarMbFV in tested garlic materials. GarMbFV was not previously identified from Poland, and the other allexivirus species were identified from Poland only recently (Chodorska et al. 2012, 2013). According to our knowledge, GarMbFV had been detected in Argentina (Helguera et al. 1997), South Korea (Kang et al. 2007) and Brazil (Oliveira et al. 2014). ShVX was not detected in any of the samples tested. Chinese garlic plants were infected with GarV-A, GarV-B, GarV-D and GarV-X, while only GarV-D and GarV-X occurred in bulbs from Spain. Wylie et al. (2014) identified only GarV-X in garlic bulbs imported from Spain, and they did not detect any allexivirus in plant materials from
China, while Parrano et al. (2015) identified GarV-X in plant materials derived from China. The largest amounts of bulbs from different parts of the world were infected with GarV-D and GarV-X, whereas GarV-C was detected in only a few bulbs from Poland. These data are confirmed by the research conducted by Parrano et al. (2012) and Wylie et al. (2014). The presence of allexiviruses species in the materials tested appears to be incidental. No domination of one particular virus species is observed, which was also reported by Dovas et al. (2001) and Fayad-André et al. (2011). This is most likely associated with the transmission of viruses by Aceria tulipae, which occurs mainly during the storage of garlic bulbs (Mann and Minges 1958).

Isolates of each detected virus were selected from positive samples, and obtained sequences were deposited in GenBank. Further analyses were performed based on the sequences of the CPs of $80 \mathrm{GarV}-\mathrm{A}$ isolates (four isolates from Poland, 11 isolates from China and 65 isolates from other countries retrieved from GenBank), 87 GarV-B isolates (three isolates from Poland, five isolates from China and 79 isolates from other countries retrieved from GenBank), 144 GarV-D isolates (10 isolates from Poland, 24 isolates from China, eight isolates from Spain and 102 isolates from other countries retrieved from GenBank), 91 GarV-X isolates (3 isolates from Poland, two isolates from China, four isolates from Spain and 82 isolates from other countries retrieved from GenBank) and 17 GarMbFV isolates (eight isolates from Poland and nine isolates from other countries retrieved from GenBank). During construction of phylogenetic trees, isolates showing $100 \%$ identity and originating from the same country were removed. The

Table 2 Viruses detected from garlic (Allium sativum) plants

\begin{tabular}{|c|c|c|c|c|c|c|c|c|}
\hline \multirow[t]{2}{*}{ Origin of plant } & \multirow[t]{2}{*}{$\begin{array}{l}\text { The number of } \\
\text { the samples tested }\end{array}$} & \multicolumn{7}{|c|}{$\begin{array}{l}\text { The number of the samples infected with virus } \\
\text { The percentage of the samples infected with virus }\end{array}$} \\
\hline & & GarV-A & GarV-B & GarV-C & GarV-D & GarV-X & GarMbFV & ShVX \\
\hline China & 72 & $\begin{array}{l}13 \\
18 \%\end{array}$ & $\begin{array}{l}10 \\
13 \%\end{array}$ & $\begin{array}{l}0 \\
0 \%\end{array}$ & $\begin{array}{l}68 \\
94 \%\end{array}$ & $\begin{array}{l}51 \\
70 \%\end{array}$ & $\begin{array}{l}0 \\
0 \%\end{array}$ & $\begin{array}{l}0 \\
0 \%\end{array}$ \\
\hline Poland & 50 & $\begin{array}{l}10 \\
20 \%\end{array}$ & $\begin{array}{l}12 \\
24 \%\end{array}$ & $\begin{array}{l}4 \\
8 \%\end{array}$ & $\begin{array}{l}50 \\
100 \%\end{array}$ & $\begin{array}{l}40 \\
80 \%\end{array}$ & $\begin{array}{l}37 \\
74 \%\end{array}$ & $\begin{array}{l}0 \\
0 \%\end{array}$ \\
\hline Spain & 24 & $\begin{array}{l}0 \\
0 \%\end{array}$ & $\begin{array}{l}0 \\
0 \%\end{array}$ & $\begin{array}{l}0 \\
0 \%\end{array}$ & $\begin{array}{l}22 \\
91 \%\end{array}$ & $\begin{array}{l}13 \\
54 \%\end{array}$ & $\begin{array}{l}0 \\
0 \%\end{array}$ & $\begin{array}{l}0 \\
0 \%\end{array}$ \\
\hline Total & 146 & $\begin{array}{l}23 \\
15 \%\end{array}$ & $\begin{array}{l}22 \\
15 \%\end{array}$ & $\begin{array}{l}4 \\
3 \%\end{array}$ & $\begin{array}{l}140 \\
96 \%\end{array}$ & $\begin{array}{l}104 \\
71 \%\end{array}$ & $\begin{array}{l}37 \\
25 \%\end{array}$ & $\begin{array}{l}0 \\
0 \%\end{array}$ \\
\hline
\end{tabular}


phylogenetic trees constructed using the ML and NJ methods were identical; therefore we presented here only the tree obtained with the ML method.

GarV-A isolates shared only 79-100\% nt and 92$100 \%$ aa identity. The comparison of amino acid sequences of the CPs of 15 GarV-A isolates obtained in this study (four isolates from Poland and 11 isolates from China) indicated very high identity of $98-100 \%$. Based on the phylogenetic tree (Fig. 1a), it is impossible to distinguish the major GarV-A isolate lineages. Based on the construction of the tree, two isolates, WA6 from Australia and GarVA-SP from Spain, are the most remote from all isolates. Wylie et al. (2014) stated that the WA6 isolate, with two other isolates, is basal to other known isolates, and that they are probably closest to ancestral isolates. Based on our results, we can also advance the hypothesis that the isolates WA6 and GarVA-SP are closest to ancestral isolates.

Nucleotide and amino acid identity of GarV-B isolates was higher, at $85-100 \% \mathrm{nt}$ and $95-100 \%$ aa, respectively. Isolates from Poland and China obtained during this research shared $97-99 \%$ aa sequence identity. Five new isolates from China (isolates 539 GarV-B, 542_GarV-B, 546_GarV-B, 549_GarV-B and

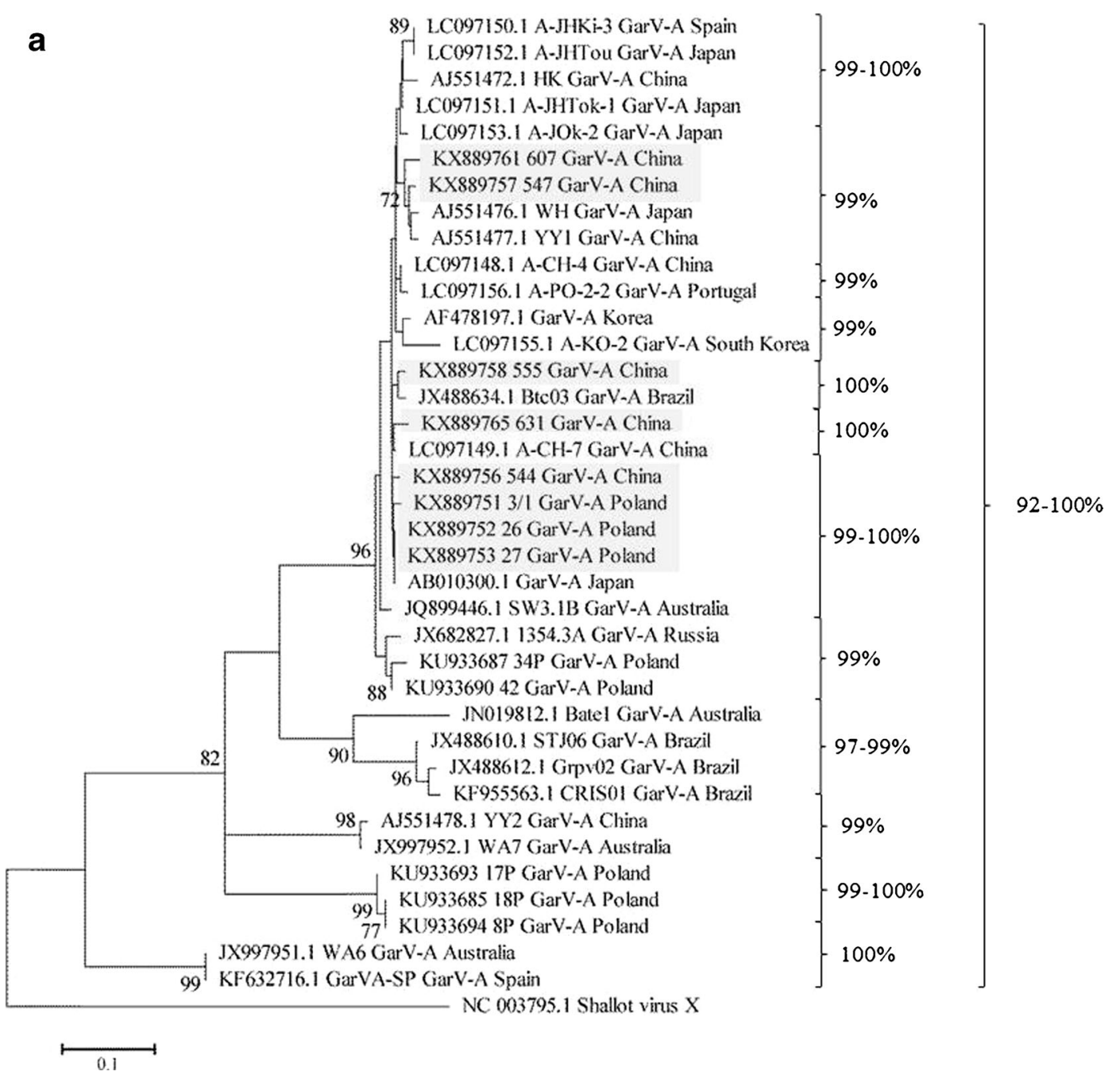

Fig. 1 Maximum likelihood phylogenetic trees of amino acid sequences of CPs of isolates of GarV-A (a), GarV-B (b), GarV-D (c), GarV-X (d) and GarMbFV (e). Percentages of replicate maximum likelihood trees in which the associated taxa clustered together in the bootstrap test (1000 replicates) are shown next to the branches. The corresponding sequence of Shallot virus $X$ (ShVX) was used as an out-group. Shown for each isolate are GenBank accession code, isolate name and country of origin. Isolates obtained in this study are indicated by a grey background 

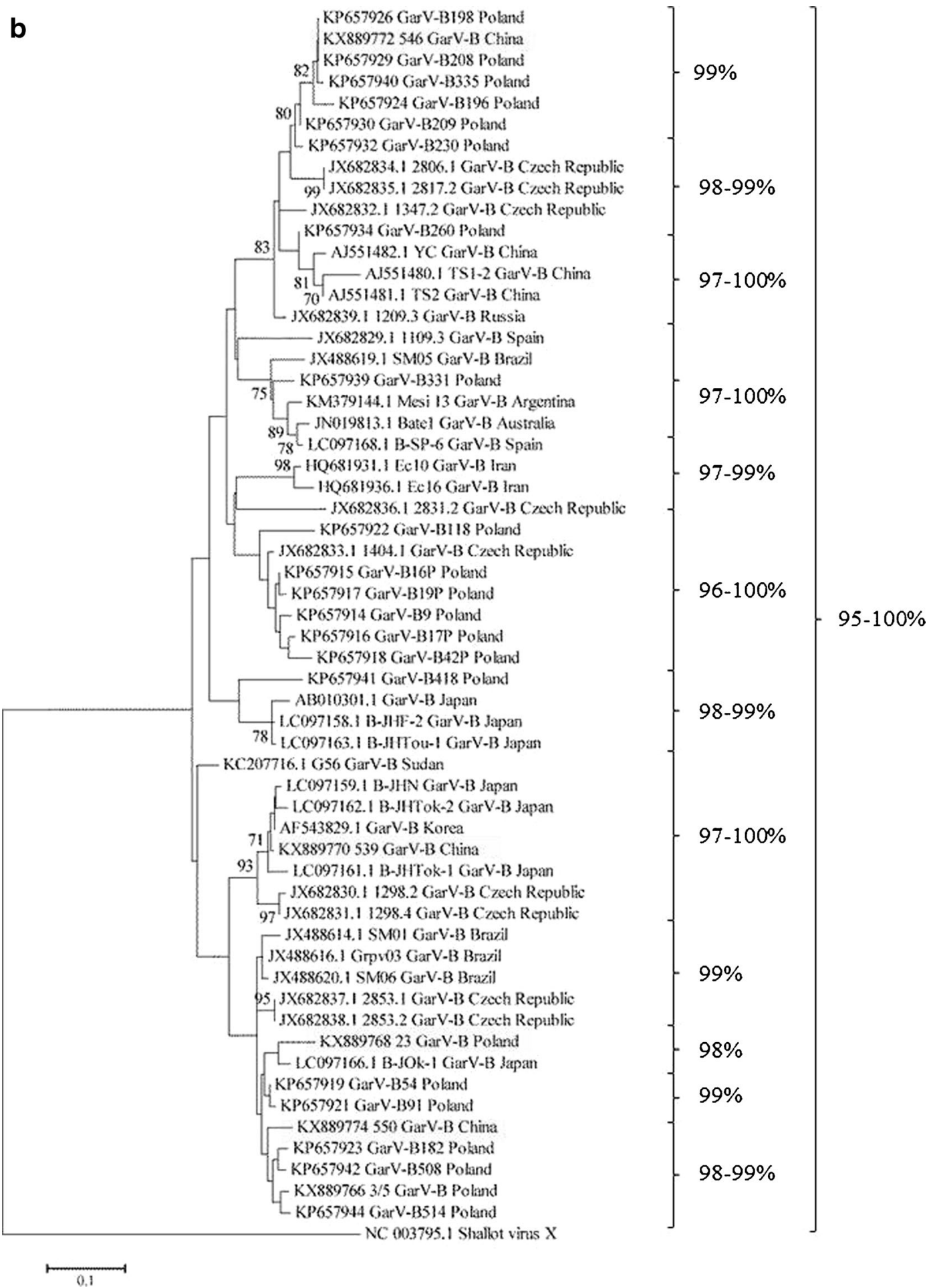

0.1

Fig. 1 (continued)

$550 \_$GarV-B) were very close (97-100\% aa identity) to previously identified isolates, whereas three new isolates from Poland (isolates 17_GarV-B, 23_GarV-B and 27_GarV-B) were more genetically distant (95- 
c

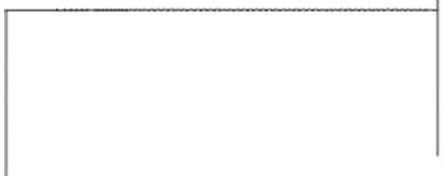

JX682876.1 1229.4 GarV-D Cyech Republic

AJ551489.1 \&Z GarV-D Chira: Gitangxi Zhang A.R. Liwhou

JX682868.3 1058.3 GarV-D Crech Republic

AJ551495. 1 YYI GarV-D China:liangxi Yivan

AJ551492.1 WH GarV-D China:Hubei Wuhan

AF519572.1 GarV.D Korea

LC097179.1 D.CH-4 GorV-1) (China

EC097181.1 D-JHU - I GarV-D Japan: Hokkaido

AJ551493.1 XA GarV-D China:Shanxi Xian

JX682878.1 1343.1 GarV-D Czech Republic

JX682865. I 1025.2 GarV-D Cech Republic

AJ551497.1 Z HaZ GarV-D China:Fujian Zhangehou

AJ551486.1 DL, GarV-D China:Yunnan Dali

JX682877.1 1297.1 GarV-D Caseh Republic

Al551483.1 AB GarV-D China:Sichum Aba Tibetan and Qiang autotomous

KX889776 3/5 GarV-1) Poland

KF 446186334 GarV-D Pohund

KF555653.1 (GarViD-SW 10 GarV-D Argnetina

AB010303.1 GarV-D Japan

KX889775 3il GarV-D Poland

KF446194 271 GarV-D Poland

- L38892.1 UK garlic isotate GarV-D Russia

- KF446206 113 GarV-D Poland

3X682806.1 1025.3 GarV.D Crech Republic

3X682864.1 1025.1 GarV-D Czech Republic

KF 446203206 GarV-D Pokand

LC097178.1 D-CH-3-1 GarV-D China

KX889789547 GarV-D China

KF550407.1 (GarVD-SW9 GarV-D Argemtina

KX889812 569 GarV-D Spain

KF 446190329 GarV-D Poland

As551491.1 TM GarV-D Chinasilin Tumen

AJ551484.1 CFH GarV-D China:lner Mongolia A.R. Hongshan county

JX488622.1 Btcol GarV-D Brazil

- KX889777 3/11 GarV-D Poland

JX682883.1 2808.2 GarV-D Crech Republic

HQ724847.1 GarV-8 GarV.D Spain

HQ724846.1 GarV-7 GarV-D Spain

KR819505.1 Mesi13 GarV-D Argentina

JX682887.1 1361.2 GarV-D Russia

KF 446199 230 GarV-D Poland

JX682870.1 1074.1 GarV-D Hungary

KF 446201 227 (GarV-D) Poland

JX682884.1 2842.2 GarV.D Crech Republic

JX682879.1 1403.2 GarV-D Skovakia

L C C97182.1 D-JM GarV-D Japan: Mivagi

IC097180.1 D-JHTok-1 GarV-D Sapan: Hokkaido

JX488624.1 STJ10 GarV.D Brazil

JN019815.1 Batel GarV-D Australia

JX682885.1 1209.1 GarV-D Russia

JX682872.1 / 127.1 GarV-1) Hungary

HQ724843.1 GarV-4 GarV-D Spain

LC097183.1 D-SP-8 GarV-D Spain

IX682880.1 1403.3 GarV-1) Shovakia

JX682873.1 1160.1 GarV-1) Cach Republic

HO681925.1 Eel GarV-D Iran

JX682886.1 1209.2 GarV-D Russia

SX682871.1 1109.2 GarV-D Spain

JX682867.1 1058.2 GarV-D Czech Republic

- I 1 Q681930.1 Ee? GarV-D Iran

- HQ724840.1 GarV-1 GarV.D Spain

JX682881.1 2806.4 GarV-D Czech Republic

IX682882.1 2806.2 GarV-D Czech Republic

IV 724844.1 GarV-5 GarV-D Spain

JX682863.1 1164.2 GarV-0 Czech Republic

NC 003795.1 Shallot vinus $X$

Fig. 1 (continued) 


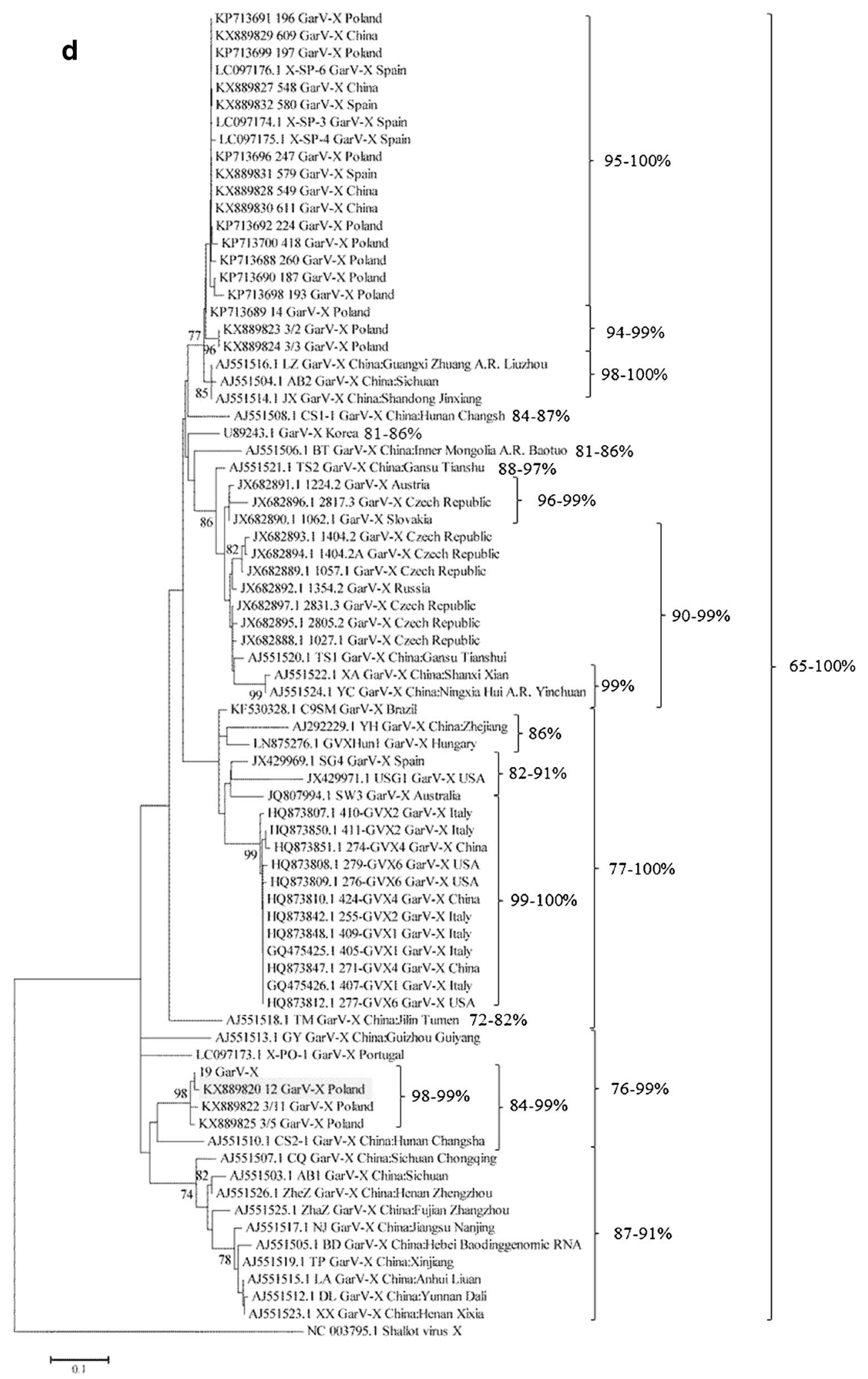

Fig. 1 (continued) 


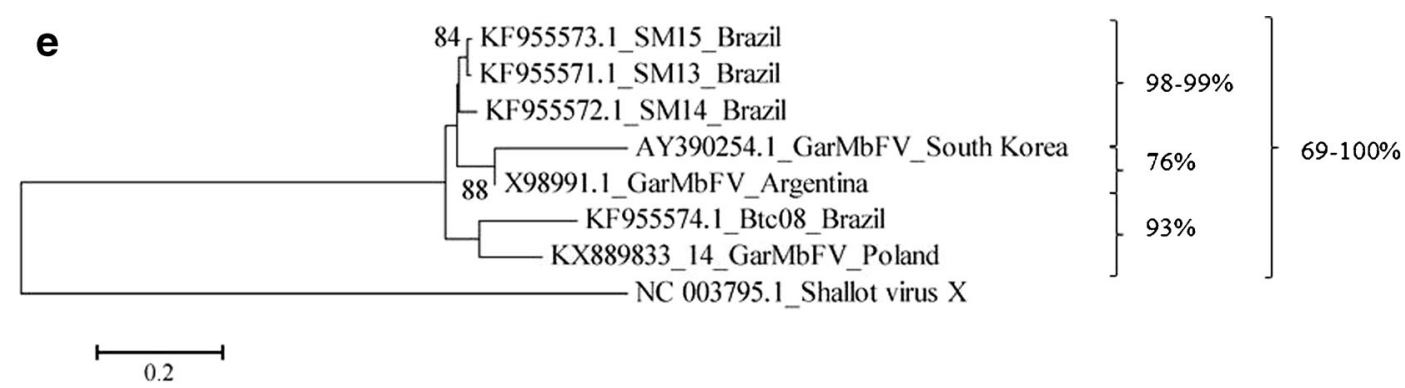

Fig. 1 (continued)

99\% aa identity with other described isolates). A phylogenetic analysis (Fig. 1b) showed that the divergent isolates belong to two major GarV-B isolate lineages, i.e. the lineage represented by isolates from Poland, China, Czech Republic, Russia, Spain, Brazil, Argentina, Australia, Iran and Japan, and the second lineage represented by isolates also from Poland, China, Czech Republic, Brazil and Japan, and additionally from Sudan and Korea. The majority of the prior studies have indicated a lack of genetic differentiation and frequent gene flow of the genus Allexivirus among various countries or several areas in one country (Koo et al. 2002; Chen et al. 2004; Melo-Filho et al. 2004; Wylie et al. 2012; Wylie et al. 2014).

A large group of GarV-D isolates indicated very low diversity. All compared isolates showed $85-100 \% \mathrm{nt}$ and $95-100 \%$ aa identity. The same value of identity was obtained for a smaller number of isolates of the research conducted in 2014 (Bereda et al. 2015). High identity was confirmed by a phylogenetic analysis (Fig. 1c). Isolates' distribution on phylogenetic tree indicates that probably all known isolates are closest to ancestral isolates. New isolates from China and Spain were identical and also shared $100 \%$ aa identity with isolates from Poland (271_GarV-D), Argentina (GarVDSW9) and China (D-CH-3-1).

When the amino acid sequences of the CPs of GarV$\mathrm{X}$ isolates were aligned, new isolates were close to some isolates identified previously, while they were also distant to the other isolates. New isolates from China, Spain and Poland shared $86-100 \mathrm{nt}$ and $69-100 \%$ aa identity with previously identified isolates. All isolates of GarV$\mathrm{X}$ shared only $65-100 \%$ aa identity. Isolates YH from China and USG1 from USA were the most genetically distant GarVX isolates identified so far (65-86 and 69$85 \%$ aa identity with other described isolates). New isolates from China and Spain identified in Poland were closely related to isolates previously identified in Poland (197_GarV-X, 247_GarV-X, 224_GarV-X, 418 GarV-X, 260_GarV-X, 187 GarV-X, 193_GarV-X) (Fig. 1d). It may indicate that they have acquired the virus through the vector during storage with garlic after import to Poland.

Eight new GarMbFV isolates were detected in bulbs derived from Poland. The sequence of these isolates was identical and shared 71-93\% identity with other described isolates. The GarMbFV isolate from South Korea shared only $69-76 \%$ aa identity with previously identify isolates, which places them slightly below the allexivirus species demarcation point of $<80 \%$ aa identity between CPs of distinct allexivirus species (King et al. 2012; Adams et al. 2004). Phylogenetic analysis showed that new isolates from Poland are very close to the isolate from Brazil (93\% aa identity) (Fig. 1e).

The detection of allexiviruses in garlic bulbs available on the retail market has unquestionable significance for basic research. The results obtained in this study do not indicate clearly that the imported garlic was infected with viruses. Considering that the isolates from China and Spain were closely related to isolates from Poland, this may indicate that they became infected with viruses via a vector during transport or storage. This certainly applies to some of the isolates. However, some of the new isolates were closely related to the isolates from their countries of origin. The results, once again, confirm that the exchange of plant materials increases the risk of introducing new virus species as well as new isolates of viruses already present, which could constitute a real threat to domestic planting in the future. Therefore, the intense development of international trade in plant materials, especially in propagating material, which contributes significantly to the spread of plant pathogens, should take place in compliance with the appropriate phytosanitary requirements. 
Open Access This article is distributed under the terms of the Creative Commons Attribution 4.0 International License (http:// creativecommons.org/licenses/by/4.0/), which permits unrestricted use, distribution, and reproduction in any medium, provided you give appropriate credit to the original author(s) and the source, provide a link to the Creative Commons license, and indicate if changes were made.

\section{References}

Adams, M. J., Antoniw, J. F., Bar-Joseph, M., et al. (2004). The new plant virus family Flexiviridae and assessment of molecular criteria for species demarcation. Archives of Virology, 149, 1045-1060.

Bereda, M., \& Paduch-Cichal, E. (2016). First report of Shallot virus $X$ in Allium caeruleum in Poland. Plant Disease, 100(9), 1958.

Bereda, M., Kalinowska, E., Paduch-Cichal, E., et al. (2015). Low genetic diversity of a natural population of Garlic virus $D$ from Poland. European Journal of Plant Pathology, 142(2), 411-417.

Boom, R., Sol, C. J. A., Salimans, M. M. M., et al. (1990). Rapid and simple method for purification of nucleic acids. Journal of Clinical Microbiology, 28, 495-503.

Cafrune, E. E., Balzarini, M., \& Conci, V. C. (2006). Changes in the concentration of an Allexivirus during the crop cycle of two garlic cultivars. Plant Disease, 90(10), 1293-1296.

Chen, J., Zheng, H. Y., Antoniw, J. F., et al. (2004). Detection and classification of allexiviruses from garlic in China. Archives of Virology, 149, 435-445.

Chodorska, M., Nowak, P., Szyndel, M. S., et al. (2012). First report of Garlic virus A, garlic virus B and Garlic virus $C$ in garlic in Poland. Journal of Plant Pathology, 94, S4.100.

Chodorska, M., Paduch-Cichal, E., Kalinowska, E., et al. (2013). Occurrence of the viruses belonging to the Allexivirus genus on garlic plants in Poland. Progress in Plant Protection/ Postęyy w Ochronie Roślin, 53(3), 605-609.

Conci, V. C., Nome, S. F., \& Milne, R. G. (1992). Filamentous viruses of garlic in Argentina. Plant Disease, 76, 594-596.

Conci, V. C., Canavelli, A. E., \& Balzarini, M. G. (2010). The distribution of garlic viruses in leaves and bulbs during the first year of infection. Journal of Phytopathology, 158, 186193.

Dovas, C. I., \& Vovlas, C. (2003). Viruses infecting Allium spp. in southern Italy. Journal of Plant Pathology, 85, 135.

Dovas, C. I., Hatziloukas, E., Salomon, R., et al. (2001). Incidence of viruses infecting Allium spp. in Greece. Phytopathology, 149, 1-7.

Fayad-André, M. S., Dusi, A. N., \& Resende, R. O. (2011). Spread of viruses in garlic fields cultivated under different agricultural production systems in Brazil. Tropical Plant Pathology, 36(6), 341-349.

Gieck, S. L., Hamm, P. B., David, N. L., et al. (2009). First report of Garlic virus $B$ and Garlic virus D in garlic in the Pacific northwest. Plant Disease, 93, 431.

Hall, T. A. (1999). BioEdit: a user-friendly biological sequence alignment editor and analysis program for windows 95/98/ NT. Nucleic Acids Symposium Series, 41, 95-98.
Helguera, M., Bravo-Almonacid, F., Kobayashi, K., et al. (1997). Immunological detection of a GarV-type virus in argentine garlic cultivars. Plant Disease, 81, 1005-1010.

Jemal, K., Abraham, A., \& Feyissa, T. (2015). The occurrence and distribution of four viruses on garlic (Allium sativum L.) in Ethiopia. International Journal of Basic and Applied Sciences, 4(1), 5-11.

Kang, S. G., Bong, J. K., Eun, T. L., et al. (2007). Allexivirus transmitted by eriophyoid mites in garlic plants. Journal of Microbiology and Biotechnology, 17, 1833-1840.

King, A. M. Q., Adams, M. J., Carstens, E. B., et al. (2012). Ninth report of the international committee on taxonomy of viruses. San Diego: Elsevier Academic Press.

Klukáčková, J., Navratil, M., \& Duchoslav, M. (2007). Natural infection of garlic (Allium sativum L.) by viruses in the Czech Republic. Journal of Plant Diseases and Protection, 114(3), 97-100.

Koo, B. J., Kang, S. G., \& Chang, M. U. (2002). Survey of garlic virus disease and phylogenetic characterization of garlic viruses of the genus Allexivirus isolated in Korea. Journal of Plant Pathology, 18, 237-243.

Malinowski, T. (1997). Silica capture-reverse transcription-polymerase chain reaction (SC-RT-PCR): application for the detection of several plant viruses. Diagnosis and Identification of Plant Pathogens, 11, 445-448.

Mann, L. K., \& Minges, P. A. (1958). Growth and bulbing of garlic (Allium sativum L.) in response to storage temperature of planting day length and planting date. Hilgardia, 27, 385419.

Marjanowski, A. (1988). Problemy hodowli i ocena wartości gospodarczej typów czosnku znajdujących się w kolekcji Instytutu Warzywnictwa. Nowości Warzywnicze, 20, 5-10.

Melo-Filho, P. A., Nagata, T., Dusi, A. N., et al. (2004). Detection of three Allexiviruses species infecting garlic in Brazil. Pesquisa Agropecuaria Brasileira, 39, 375-340.

Mohammed, H. S., Zicca, S., Manglli, A., et al. (2013). Occurrence and phylogenetic analysis of Potyviruses, Carlaviruses and Allexiviruses in garlic in Sudan. Journal of Phytopathology, 161(9), 642-650.

Oliveira, M. L., De Marchi, D. R., Mituti, T., et al. (2014). Identification and sequence analysis of five allexiviruses species infecting garlic crops in Brazil. Tropical Plant Pathology, 39(6), 483-489.

Parrano, L., Afunian, M., Pagliaccia, D., et al. (2012). Characterization of viruses associated with garlic plants propagated from different reproductive tissues from Italy and other geographic regions. Phytopathologia Mediterranea, 51(3), 549-565.

Perotto, M. C., Cafrune, E. E., \& Conci, V. C. (2010). The effect of additional viral infections on garlic plants initially infected with Allexiviruses. European Journal of Plant Pathology, 126(4), 489-495.

Shahraeen, N., Lesemann, D. E., \& Ghtbi, T. (2008). Survey for viruses infecting onion, garlic and leek crops in Iran. $O E P P /$ EPPO Bulletin, 38, 131-135.

Singh, P., Prabha, K., Jain, R. K., \& Baranwal, V. K. (2014). Nterminal in coat protein of Garlic virus $X$ is indispensible for its serological detection. Virus Genes, 48(1), 128-132.

Song, S. I., Song, J. T., Chang, M. U., et al. (1997). Identification of one of the major viruses infecting garlic plants, Garlic virus X. Molecules and Cells, 7, 705-709. 
Sumi, S., Tsuneyoshi, T., \& Furutani, H. (1993). Novel rod-shaped viruses isolated from garlic, Allium sativum, possessing a unique genome organization. Journal of General Virology, 74, 1879-1885.

Tabanelli, D., Bertaccini, A., \& Bellardi, M. G. (2004). Molecular detection of filamentous viruses infecting garlic from different geographic origins. Journal of Plant Pathology, 86(4), 335-335.

Tamura, K., Peterson, D., Peterson, N., et al. (2011). MEGA5: molecular evolutionary genetics using maximum likelihood, evolutionary distance, and maximum parsimony methods. Molecular Biology and Evolution, 28, 2731-2739.
Vishnichenko, V. K., Konareva, T. N., \& Zavriev, S. K. (1993). A new filamentous virus in shallot. Plant Pathology, 42, 12-126.

Ward, L. I., Perez-Egusquiza, Z., Fletcher, J. D., \& Clover, G. R. G. (2009). A survey of viral diseases of Allium crops in New Zealand. Australasian Plant Pathology, 38, 533-539.

Wylie, S. J., Li, H., \& Jones, M. G. K. (2012). Phylogenetic analysis of allexiviruses identified on garlic from Australia. Australasian Plant Disease Notes, 7, 23-27.

Wylie, S. J., Hua, L., Saqib, M., \& Jones, M. G. K. (2014). The global trade in fresh produce and the vagility of plant viruses: a case study in garlic. PloS One, 9(8), e105044. 